\title{
ВПЛИВ ЧАСУ ПРИБУТТЯ ПІДРОЗДІЛІВ ПОЖЕЖНОЇ ОХОРОНИ ДО МІСЦЯ ВИКЛИКУ НА ТРИВАЛІСТЬ ГАСІННЯ ПОЖЕЖІ НА ТЕРИТОРІЇ ЗОНИ ВІДЧУЖЕННЯ
}

\author{
https://doi.org/10.33269/nvcz.2021.2.11-19
}

\author{
Циганков A. O.* ORCID iD 0000-0003-1971-9640 \\ Ніжник B. B., ORCID iD 0000-0003-3370-9027 \\ Балло Я. В., ORCID iD 0000-0002-9044-1293 \\ Сізіков О. О.,ORCID iD 0000-0002-7861-3144 \\ Жихарєв О. П., ORCID iD 0000-0003-4323-1880 \\ Тесленко O. М., ORCID iD 0000-0002-1003-8876 \\ *E-mail:0502879336@ukr.net
}

Інститут державного управління та наукових досліджень з цивільного захисту, Україна

ІНФОРМАЦІЯ ПРО СТАТТЮ

Надійшла до редакції: 22.09.2021

Пройшла рецензування: 09.10.2021

КЛЮЧОВІ СЛОВА:

вогнезахисні засоби,

вогнезахищена деревина, строк

придатності, умови зберігання,

група вогнезахисної ефективності.

\begin{abstract}
АНОТАЦІЯ
За результатами наукових досліджень визначено залежність кількості залучених пожежних автомобілів, людських ресурсів та тривалості гасіння пожежі на території зони відчуження від часу прибуття підрозділів пожежної охорони до місця виклику. На основі статистичних даних встановлено: якщо час прибуття на пожежу підрозділів пожежної охорони складає понад 20 хв, то тривалість гасіння пожежі збільшується в 5 та більше разів, у 3 рази більше залучається основних та допоміжних пожежних автомобілів та до 3 разів більше людських ресурсів порівняно з часом прибуття до місця пожежі менше 20 хв. За результатами досліджень науково обґрунтовано зміни до законодавчих та нормативно-правових актів щодо забезпечення пожежної безпеки на території зони відчуження.
\end{abstract}

Постановка проблеми. Утворення підрозділів пожежної охорони (далі ППО), а саме - пожежно-рятувальних підрозділів Державної служби України 3 надзвичайних ситуацій (далі - ДСНС) та підрозділів відомчої (або добровільної) пожежної охорони суб'єктів господарювання, що належать до сфери управління Державного агентства зони відчуження (далі - ДАЗВ), на території зони відчуження повинно відповідати вимогам чинних законодавчих та нормативноправових актів 3 подальшим визначенням територій та об'єктів, які ними обслуговуються.

Актуальність цієї роботи зумовлена нинішньою негативною динамікою зміни рівня загроз техногенного i природного характеру та нормативно-правовою неврегульованістю забезпечення пожежної безпеки на території зони відчуження, необхідністю підтримання достатнього рівня безпеки людей, які перебувають, працюють і проживають на ній, захисту лісів на цій території.

Для уникнення або мінімізації наслідків надзвичайних ситуацій, у тому числі пожеж, на зазначеній території необхідно провести дослідження щодо визначення впливу часу прибуття ППО до місця виклику на тривалість гасіння пожежі, кількість залучених пожежних автомобілів та людських ресурсів для іiі ліквідації та науково обгрунтувати відповідні зміни до законодавчих i нормативно-правових актів.

Аналіз попередніх досліджень і публікацій. Питанням досліджень щодо 
забезпечення пожежної безпеки на території зони відчуження присвячено ряд праць [1-6]. В них розглянуто та визначено потенційні загрози і небезпеки на цій території, проаналізовано статистичні дані щодо залучення протипожежної техніки до гасіння пожеж.

У роботі [1] проведено моделювання оперативної обстановки в зоні відчуження залежно від кількості протипожежної техніки, що залучається для обслуговування одного виклику, потоку викликів та тривалості обслуговування ППО одного виклику. Визначено зони обслуговування ППО і лісових пожежних станцій на цій території та встановлено їх оптимальну кількість за критерієм часу прибуття ППО.

У статті [4], зокрема, згідно з аналізом статистичних даних встановлено ймовірність залучення протипожежної техніки до ліквідації однієї пожежі у зоні відчуження.

У роботі [6] проаналізовано час прибуття пожежно-рятувальних підрозділів м. Львова до місця пожежі з використанням електронної карти.

Питання визначення впливу часу прибуття ППО до місця виклику на тривалість гасіння пожежі на території зони відчуження, а також аналіз чинної законодавчої та нормативно-правової бази для наукового обгрунтування пропозицій щодо змін до законодавчих та нормативноправових актів 3 метою зниження пожежних ризиків на цій території в наукових публікаціях не розглядалися.

Формулювання цілей досліджень. Метою цієї роботи є виявлення впливу часу прибуття ППО до місця виклику на тривалість гасіння пожежі на території зони відчуження та обгрунтування відповідних змін до нормативно-правових актів.

Для досягнення поставленої мети сформовано такі задачі:

- провести аналіз статистичних даних про пожежі у зоні відчуження для визначення впливу часу прибуття ППО до місця виклику на тривалість гасіння пожеж;
- здійснити аналіз статистичних даних про пожежі для визначення впливу часу прибуття ППО на кількість залучених основних та допоміжних пожежних автомобілів, особового складу та працівників ППО для гасіння пожеж у зоні відчуження;

- провести аналіз чинної законодавчої та нормативно-правової бази та науково обгрунтувати пропозиції стосовно змін до законодавчих та нормативно-правових актів щодо забезпечення пожежної безпеки на території зони відчуження.

Об'єкт дослідження - тривалість гасіння пожежі й залучення сил та засобів ППО для ії ліквідації на території зони відчуження.

Предмет дослідження - вплив часу прибуття ППО до місця виклику на тривалість гасіння пожежі, кількість залучених пожежних автомобілів та людських ресурсів для iї ліквідації на території зони відчуження.

Методи дослідження. У роботі було використано методи інтерполяції та усереднення, проводився аналіз нормативних документів, згідно 3 якими регламентована діяльність суб'єктів господарювання у зоні відчуження. Під час досліджень визначали розподіл тривалості гасіння пожеж на цій території до 8 год та їх відповідної відносної кількості у разі часу прибуття ППО до місця пожежі до 20 хв та у разі часу прибуття ППО більше 20 хв, залежність тривалості гасіння пожеж у зоні відчуження від часу прибуття ППО до місця пожежі, залежність кількості залучених пожежних автомобілів і середньої кількості осіб особового складу та працівників ППО, залучених на іiі ліквідацію, від часу прибуття ППО до місця виклику пожежі.

Виклад основного матеріалу. Відповідно до постанови КМУ [7] впроваджено критерії, за якими утворюються державні пожежнорятувальні підрозділи (частини) оперативно-рятувальної служби цивільного захисту в адміністративно-територіальних одиницях, якими $\epsilon$ : кількість жителів 
населеного пункту; радіус обслуговування одним державним пожежно-рятувальним підрозділом (частиною) та норматив часу прибуття державних пожежно-рятувальних підрозділів (частин) до місця виклику, який для сільської місцевості складає 20 хв. Враховуючи специфіку території зони відчуження, а саме - бар'єрне функціонування, відсутність населених пунктів та населення в них, доріг загального користування, у проведених дослідженнях норматив часу прибуття ППО до місця виклику прийнято як для сільської місцевості - 20 хв. Під часом прибуття ППО від місця їх дислокації до місця надзвичайної події (зокрема пожежі) розуміється час із моменту отримання повідомлення про надзвичайну подію до моменту прибуття до місця, де вона виникла.

На основі аналізу статистичних даних про пожежі на території зони відчуження за 2016-2020 роки, наданих ГУ ДСНС України у Київській області, визначено усереднені дані щодо їх загальної кількості, відстані від місць дислокації ППО до місця виникнення пожежі, часу прибуття на пожежу, тривалості іiі гасіння, часу обслуговування виклику, середньої кількості задіяних на гасіння однієї пожежі пожежних автомобілів, особового складу та працівників ППО, що наведено у табл. 1 .

Таблиця 1 - Статистичні дані про пожежі на території зони відчуження за 2016-2020 pp.

\begin{tabular}{|c|c|c|c|c|c|c|}
\hline $\begin{array}{l}\text { Середня } \\
\text { відстань від } \\
\text { місця } \\
\text { дислокації } \\
\text { ППО до } \\
\text { місця } \\
\text { виникнення } \\
\text { пожежі, км }\end{array}$ & $\begin{array}{l}\text { Середній } \\
\text { час } \\
\text { прибуття } \\
\text { ППО на } \\
\text { пожежу, хв }\end{array}$ & $\begin{array}{l}\text { Середня } \\
\text { тривалість } \\
\text { гасіння } \\
\text { пожежі, год }\end{array}$ & $\begin{array}{l}\text { Середній час } \\
\text { обслуговування } \\
\text { виклику, год }\end{array}$ & $\begin{array}{l}\text { Середня } \\
\text { кількість } \\
\text { задіяних } \\
\text { пожежних } \\
\text { автомобілів } \\
\text { на гасіння } \\
\text { пожежі, } \\
\text { од./ на одну } \\
\text { пожежу }\end{array}$ & $\begin{array}{l}\text { Середня } \\
\text { кількість } \\
\text { задіяного } \\
\text { особового } \\
\text { складу та } \\
\text { працівників } \\
\text { ППО, осіб / на } \\
\text { одну пожежу }\end{array}$ & $\begin{array}{l}\text { Загальна } \\
\text { кількість } \\
\text { пожеж }\end{array}$ \\
\hline \multicolumn{7}{|c|}{2016 p. } \\
\hline 12,36 & 24,3 & 4,4 & 4,5 & 3 & 10 & 76 \\
\hline \multicolumn{7}{|c|}{2017 p. } \\
\hline 18,4 & 41 & 3,8 & 4,6 & 3 & 14 & 45 \\
\hline \multicolumn{7}{|c|}{2018 p. } \\
\hline 14,05 & 28,59 & 3,0 & 3,6 & 5 & 18 & 51 \\
\hline \multicolumn{7}{|c|}{2019 p. } \\
\hline 10,47 & 44,8 & 4,7 & 5,0 & 4 & 19 & 95 \\
\hline \multicolumn{7}{|c|}{2020 p. } \\
\hline 15,9 & 26,9 & 7,4 & 8,2 & 8 & 13 & 89 \\
\hline
\end{tabular}

Джерело: розроблено авторами

Згідно 3 аналізом статистичних даних про пожежі на території зони відчуження за 2016-2020 роки виявлено тенденцію щодо збільшення пожежних ризиків. За досліджуваний період на цій території сталося 356 пожеж; середня тривалість гасіння пожежі становила 4,7 год, а найбільша тривалість іiі гасіння 720 годин; середня відстань від місця дислокації ППО до місця виникнення пожежі в середньому складала 14,2 км; середній час прибуття ППО на пожежу становив 33 хв; в середньому на одну пожежу було задіяно п'ять пожежних автомобілів і 15 осіб особового складу та працівників ППО, а найбільша кількість залученої пожежної техніки становила 86 одиниць і 384 особи особового складу та працівників ППО.

На основі статистичних даних про пожежі на території зони відчуження визначено: розподіл тривалості гасіння пожеж до 8 год та їх відповідної кількості у разі часу прибуття ППО до місця пожежі до 
20 хв, що наведено в табл. 2; розподіл тривалості гасіння пожеж та їх відповідної кількості у разі тривалості прибуття ППО більше 20 хв, що наведено в табл. 3; розподіл тривалості гасіння пожежі до 8 год від їх відповідної відносної кількості у разі часу прибуття ППО до місця пожежі до 20 хв та у разі часу прибуття ППО більше 20 хв, що графічно наведено на рис 1.
Представлені в цій роботі результати є проміжними i потребують проведення подальших досліджень для остаточного визначення зазначеного вище показника для зразків деревини, група вогнезахисної ефективності яких не вийшла за межі, встановлені будівельними нормами [1].

Таблиия 2 - Розподіл тривалості гасіння пожежі у зоні відчуження та їх відповідної кількості у разі часу прибуття ППО до місця пожежі до 20 хв

\begin{tabular}{|c|c|c|c|c|c|c|c|c|}
\hline $\begin{array}{c}\text { Інтервал тривалості } \\
\text { гасіння пожежі } \boldsymbol{\tau}, \text { год }\end{array}$ & $\mathbf{0 - 1}$ год & $\mathbf{1 - 2}$ год & $\mathbf{2 - 3}$ год & $\mathbf{3 - 4}$ год & $\mathbf{4 - 5}$ год & $\begin{array}{c}\mathbf{5}-\mathbf{6} \\
\text { год }\end{array}$ & $\begin{array}{c}\mathbf{6}-\mathbf{7} \\
\text { год. }\end{array}$ & $\begin{array}{c}\mathbf{7 - 8} \\
\text { год }\end{array}$ \\
\hline $\begin{array}{c}\text { Абсолютна к-ть } \\
\text { пожеж, од. }\end{array}$ & 39 & 44 & 46 & 13 & 6 & 4 & 2 & 2 \\
\hline Відносна к-ть пожеж, \% & 22 & 25 & 26 & 7 & 3 & 2 & 1 & 1 \\
\hline
\end{tabular}

Таблиия 3 - Розподіл тривалості гасіння пожежі у зоні відчуження та їх відповідної кількості у разі часу прибуття ППО понад 20 хв

\begin{tabular}{|c|c|c|c|c|c|c|c|c|}
\hline $\begin{array}{c}\text { Інтервал тривалості } \\
\text { гасіння пожежі } \boldsymbol{\tau}, \text { год }\end{array}$ & $\mathbf{0 - 1}$ год & $\mathbf{1 - 2}$ год & $\mathbf{2 - 3}$ год & $\mathbf{3 - 4}$ год & $\mathbf{4 - 5}$ год & $\mathbf{5 - 6}$ год & $\mathbf{6 - 7}$ год & $\mathbf{7 - 8}$ год \\
\hline $\begin{array}{c}\text { Абсолютна к-ть } \\
\text { пожеж, од. }\end{array}$ & - & 16 & 22 & 21 & 16 & 17 & 12 & 5 \\
\hline Відносна к-ть пожеж, \% & - & 3 & 13 & 12 & 9 & 10 & 7 & 3 \\
\hline
\end{tabular}

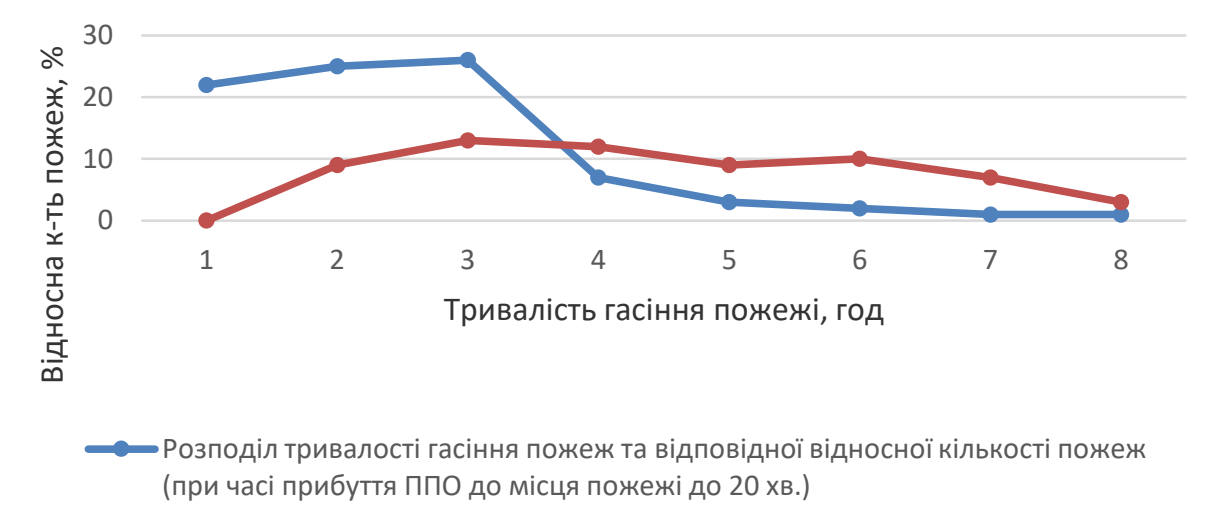

Рисунок 1 - Розподіл тривалості гасіння пожеж у зоні відчуження до 8 год та їх відповідної відносної кількості у разі часу прибуття ППО до місця пожежі до 20 хв та у разі часу прибуття ППО понад 20 хв Джерело: розроблено авторами

Аналізуючи дані, наведені в таблицях 2, 3 та рисунку 1, можна зробити висновок, що у разі часу прибуття ППО до місця пожежі до 20 хв понад 70\% пожеж у зоні відчуження ліквідують до 3 год, а у разі часу прибуття ППО до місця пожежі понад
20 хв кількість пожеж, які гасять до 3 год, складає всього $20 \%$ від загальної кількості.

На основі статистичних даних про пожежі на території зони відчуження визначено: розподіл тривалості гасіння пожеж понад 8 год та їх відповідної кількості у разі часу прибуття ППО до місця 
пожежі до 20 хв, що наведено в табл. 4; розподіл тривалості гасіння пожеж понад 8 год та їх відповідної кількості у разі часу прибуття ППО до місця пожежі понад 20 хв, що наведено в табл. 5; розподіл тривалості гасіння пожеж понад 8 год та їх відповідної кількості у разі часу прибуття ППО до місця пожежі до 20 хв та у разі часу прибуття ППО більше 20 хв, що графічно наведено на рис. 2.

Таблиия 4 - Розподіл кількості пожеж у зоні відчуження, гасіння яких відбулось у термін понад 8 год та їх відповідної тривалості гасіння у разі часу прибуття ППО до місця пожежі до 20 хв

\begin{tabular}{|c|c|c|c|c|c|c|c|}
\hline $\begin{array}{l}\text { Інтервал тривалості гасіння } \\
\text { пожежі } \tau \text {, год }\end{array}$ & 8-12 год & $\begin{array}{c}\text { 12-16 } \\
\text { год }\end{array}$ & $\begin{array}{c}\text { 16-20 } \\
\text { год }\end{array}$ & $\begin{array}{c}20-24 \\
\text { год }\end{array}$ & $\begin{array}{c}24-28 \\
\text { год }\end{array}$ & $\begin{array}{c}\text { 28-32 } \\
\text { год }\end{array}$ & $\begin{array}{c}\text { 32-36 } \\
\text { год }\end{array}$ \\
\hline Абсолютна к-ть пожеж, од. & 6 & 5 & 5 & 4 & 3 & 2 & 1 \\
\hline Відносна к-ть пожеж, \% & 3 & 3 & 3 & 2 & 2 & 1 & 1 \\
\hline
\end{tabular}

Джерело: розроблено авторами

Таблиия 5 - Розподіл кількості пожеж у зоні відчуження, гасіння яких відбулось у термін понад 8 год та їх відповідної тривалості гасіння у разі часу прибуття ППО до місця пожежі понад 20 хв

\begin{tabular}{|l|l|l|l|l|l|l|l|}
\hline $\begin{array}{l}\text { Інтервал тривалості гасіння } \\
\text { пожежі } \boldsymbol{\tau} \text {, год }\end{array}$ & $\mathbf{8 - 1 2}$ год & $\begin{array}{l}\mathbf{1 2 - 1 6} \\
\text { год }\end{array}$ & $\begin{array}{l}\mathbf{1 6 - 2 0} \\
\text { год }\end{array}$ & $\begin{array}{l}\mathbf{2 0 - 2 4} \\
\text { год }\end{array}$ & $\begin{array}{l}\mathbf{2 4 - 2 8} \\
\text { год }\end{array}$ & $\begin{array}{l}\mathbf{2 8}-\mathbf{3 2} \\
\text { год }\end{array}$ & $\begin{array}{l}\mathbf{3 2 - 3 6} \\
\text { год }\end{array}$ \\
\hline Абсолютна к-ть пожеж, од. & 6 & 7 & 11 & 8 & 4 & 2 & 2 \\
\hline Відносна к-ть пожеж, \% & 3 & 4 & 6 & 5 & 2 & 2 & 1 \\
\hline
\end{tabular}

Джерело: розроблено авторами

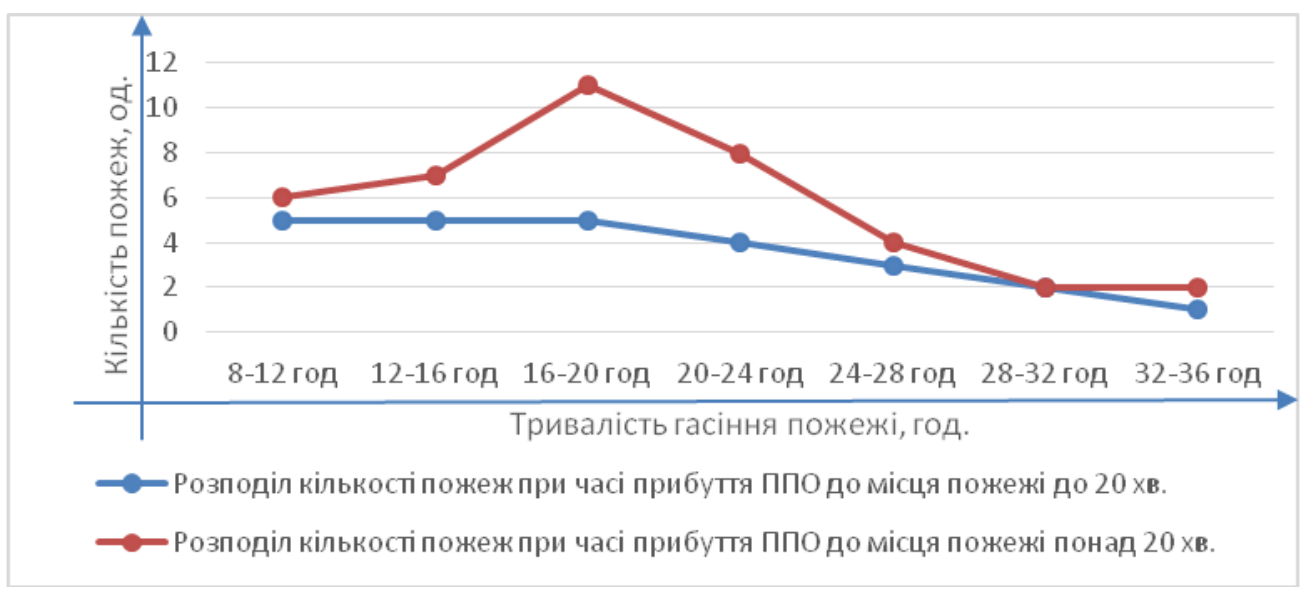

Рисунок 2 - Розподіл тривалості гасіння пожеж понад 8 год та їх відповідної кількості у разі часу прибуття ППО до місця пожежі до 20 хв та у разі часу прибуття ППО понад 20 хв

Джерело: Розроблено авторами

Зважаючи на аналіз даних, наведений в табл. 4, 5 та рис. 2, можна зробити висновок, що у разі часу прибуття ППО до місця пожежі до 20 хв кількість пожеж у зоні відчуження з тривалістю гасіння понад 8 год зменшується у 1,6 раза.

На рис. 3 на основі статистичних даних про пожежі в зоні відчуження 3 використанням методу інтерполяції наведено залежність тривалості гасіння пожеж від часу прибуття ППО до місця пожежі.
3 огляду на аналіз статистичних даних та тих, котрі наведені на рис. 3, можна зробити висновок, що пожежі, на які ППО прибували понад 20 хв, перетворювалися у складні та тривалі, на ліквідацію яких витрачалося 15 і більше годин.

На основі статистичних даних про пожежі в зоні відчуження виявлена залежність кількості залучених основних та допоміжних пожежних автомобілів до гасіння пожежі від часу прибуття ППО до місця пожежі, що представлено на рис. 4. 


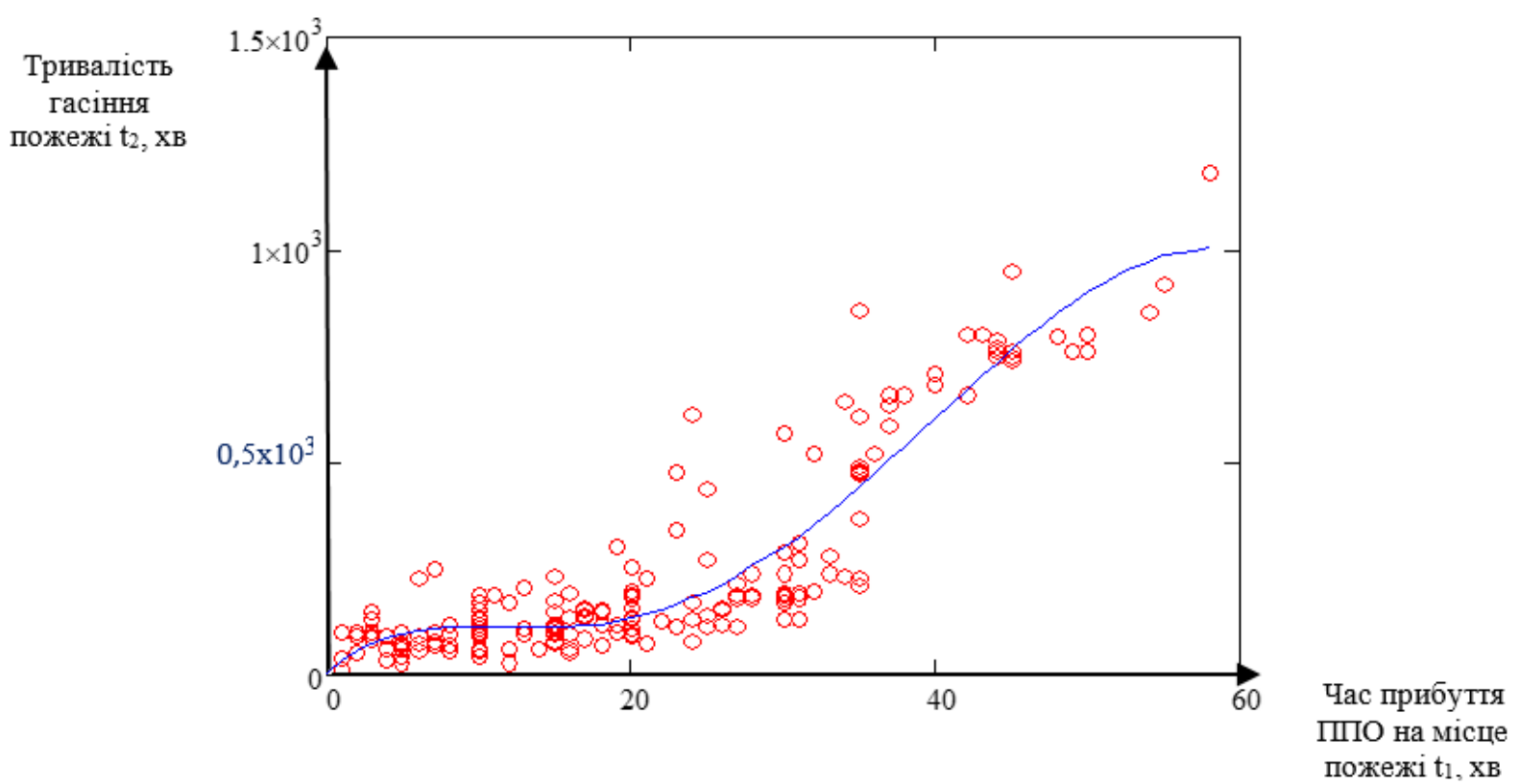

Рисунок 3 - Залежність тривалості гасіння пожеж у зоні відчуження від часу прибуття ППО до місця пожежі

Джерело: розроблено авторами

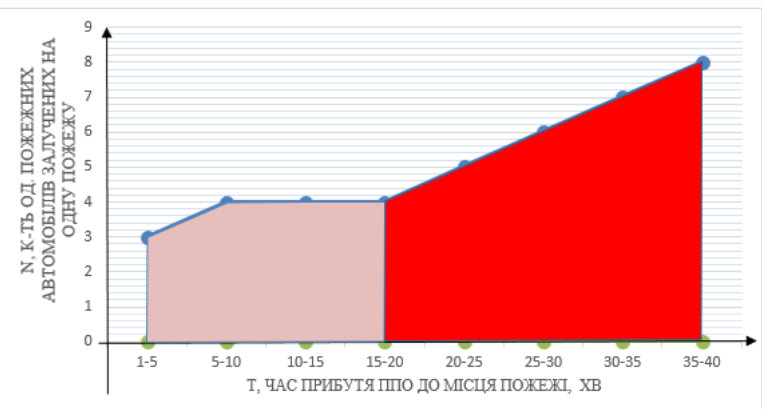

Рисунок 4 - Залежність кількості залучених пожежних автомобілів до гасіння пожежі від часу прибуття ППО до місця виклику пожежі Джерело: розроблено авторами

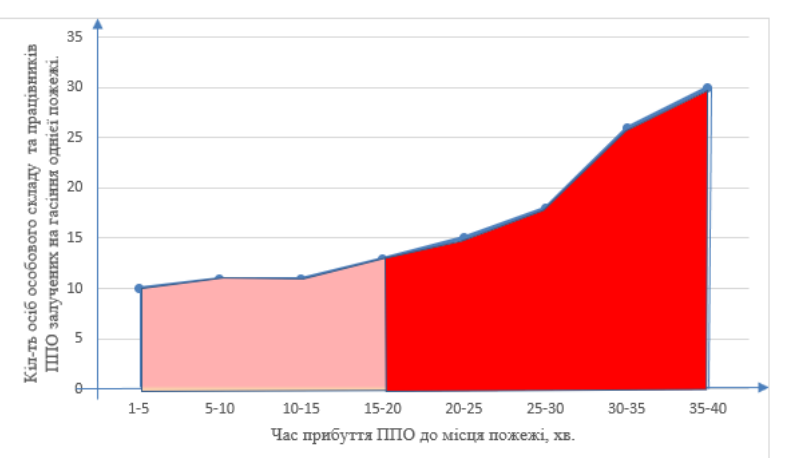

Рисунок 5 - Залежність середньої кількості осіб особового складу та працівників ППО, залучених до гасіння однієї пожежі від часу прибуття ППО до місця пожежі

Джерело: розроблено авторами
Залежність середньої кількості осіб особового складу та працівників ППО, залучених до гасіння однієї пожежі від часу прибуття ППО до місця пожежі, наведено на рис. 5.

На рис. 4 та 5 графічно зображено, що гасіння пожеж, на які підрозділи пожежної охорони прямували більше 20 хв, супроводжувалося залученням значної кількості пожежно-рятувальної та допоміжної техніки (збільшення у 3 рази) та людських ресурсів (збільшення у 3 рази) порівняно 3 тими пожежами, на які прибуття до місця їх виникнення становило менше 20 хв.

У результаті проведених наукових досліджень встановлено, що:

критичними (за критеріями: тривалість гасіння пожежі у зоні відчуження, кількість залучених для гасіння пожеж пожежних автомобілів та людських ресурсів) $\epsilon$ ті пожежі, на які час прибуття ППО складає більше 20 хв. На таких пожежах тривалість ïх гасіння до 6 разів перевищувала тривалість гасіння пожеж, на які час прибуття ППО складав менше 20 хв, 
a залучених пожежних автомобілів та людських ресурсів було утричі більше;

забезпечення часу прибуття підрозділів пожежної охорони до місця виклику менше 20 хв, а відповідно і зниження рівня загроз техногенного та природного характеру можливе, зокрема, шляхом дислокації в зоні відчуження необхідної кількості підрозділів пожежної охорони (державної, відомчої, добровільної).

Унаслідок проведеного аналізу виявлена недосконалість законодавчої та нормативно-правової бази, що досліджувалась.

Наведені вище положення зумовлюють необхідність визначення кількості та місць дислокації підрозділів пожежної охорони на території зони відчуження.

Можливість вирішення цього завдання 3 огляду на результат проведених досліджень полягає у розробці проєкту постанови Кабінету Міністрів України щодо унормування критерію, за яким утворюються підрозділи відомчої пожежної охорони на території зони відчуження суб'єктами господарювання, які належать до сфери управління ДАЗВ та територіально знаходяться в зоні відчуження.

Запропоновано, що критерієм, за яким утворюються підрозділи відомчої пожежної охорони суб'єктами господарювання, що належать до сфери управління ДАЗВ та територіально знаходяться в зоні відчуження (крім державного спеціалізованого підприємства «Чорнобильська АЕС» i об'єктів для поводження з радіоактивними відходами та їх інфраструктури, які повинні охоронятися пожежно-рятувальними підрозділами ДСНС), $€$ норматив часу прибуття підрозділів відомчої пожежної охорони від місця їх дислокації до місця надзвичайної події, який має складати не більше 20 хв 3 моменту отримання повідомлення про надзвичайну подію до моменту прибуття.

Висновки та напрями подальших досліджень. На основі аналізу статистичних даних про пожежі в зоні відчуження:

встановлено закономірність збільшення у понад 5 разів тривалості гасіння пожежі, якщо час прибуття на пожежу підрозділів пожежної охорони складав більше ніж 20 хв, а також збільшення у 3 рази кількості залучених основних i допоміжних пожежних автомобілів та людських ресурсів;

виявлено, що забезпечення часу прибуття підрозділів пожежної охорони до місця пожежі в зоні відчуження менше 20 хв, а відповідно і зниження рівня загроз техногенного та природного характеру можливе, зокрема, шляхом дислокації на цій території необхідної кількості підрозділів пожежної охорони (державної, відомчої, добровільної);

встановлено можливість визначення кількості та місць дислокації підрозділів відомчої пожежної охорони суб'єктів господарювання, що належать до сфери управління ДАЗВ та територіально знаходяться у зоні відчуження, шляхом розроблення проєкту постанови Кабінету Міністрів України щодо унормування критерію, за яким утворюються ці підрозділи та яким $\epsilon$ норматив часу прибуття підрозділів відомчої пожежної охорони від місця їх дислокації до місця надзвичайної події, що складає не більше 20 хв 3 моменту отримання повідомлення про надзвичайну подію до моменту прибуття. 


\section{СПИСОК ВИКОРИСТАНИХ ДЖЕРЕЛ}

1. Моделювання оперативної обстановки в зоні відчуження / Ніжник В. та ін. Науковий вісник : Цивільний захист та пожежна безпека. 2020. Вип. 1(9). С. 42-51.

2. Оцінка кореляції часу проведення пожежно-профілактичної роботи від кількості виїздів пожежно-рятувальних підрозділів в зоні відчуження / В. В. Ніжник та ін. Надзвичайні ситуації: попередження та ліквідачія. 2020. Вип. 4(2). С. 48-53.

3. Обгрунтування швидкості руху пожежних автомобілів для визначення дислокації пожежно-рятувальних підрозділів / О. М. Крикун та ін. Науковий вісник : Цивільний захист та пожежна безпека. 2018. Вип. 1 (5). С. $21-24$.

4. Кузик А. Д., Лагно Д. В. Особливості процесу ліквідації пожежі у забруднених радіонуклідами лісах на території зони відчуження. Fire Safety. 2019. № 34. С. 47-52.

5. Блощицкий В. П., Казанова Ю. С., Мартыненко Т. В. Определение оптимального пути следования пожарного расчета к месту пожара с помощью эволюционных вычислений. Наукові праці Дон НТУ. 2010. Вип. 23(169). С. $159-165$.

6. Кузик А. Д., Ємельяненко С. О. Оцінювання часу слідування пожежно-рятувальних підрозділів. Пожежна безпека. 2013. № 23. С. 86-92.

7. Про затвердження критеріїв утворення державних пожежно-рятувальних підрозділів (частин) Оперативно-рятувальної служби цивільного захисту в адміністративно-територіальних одиницях та переліку суб'єктів господарювання, де утворюються такі підрозділи (частини) : постанова Кабінету Міністрів України від 27.11.2013 p. № 874. URL: https://zakon.rada.gov.ua/laws/show/874-2013-\%D0\%BF\#Text (дата звернення : 05.10.2021).

\section{REFERENCES}

1. V. Nizhnyk, Yu. Feshchuk, Ya. Ballo, O. Teslenko \& A. Tsyhankov (2020). Modelyuvannya operatyvnoyi sytuaciyi v zoni vidchuzhennya [Simulation of the operational situation in the exclusion zone], Naukovyi visnyk: Tsyvilnyi zakhyst ta pozhezhna bezpeka [Scientific bulletin: civil protection and fire safety]. [in Ukrainian].

2. V. Nizhnyk, Yu. Feshchuk, O. Sizikov, Ya. Ballo, O. Zhikharev \& A. Tsyhankov (2020). Ocinka spivvidnoshennya chasu provedennya protypozhezhnyx robit z kilkistyu vylotiv pozhezhno-ryatuval `nyx pidrozdiliv u zonu vidchuzhennya [Estimation of correlation of time of carrying out fire-prevention work from number of departures of fire-rescue divisions in an exclusion zone], Nadzvychaini sytuatsii: poperedzhennia ta likvidatsiia [Emergencies: prevention and elimination]. [in Ukrainian].

3. O. Krikun, V. Kropyvnytskyi, V. Nizhnyk, O. Zhikharev \& D. Dobriak (2018). Obgruntuvannya shvydkosti ruxu pozhezhny’x avtomobiliv dlya vyznachennya dyslokaciyi pozhezhno-ryatuvalny`x pidrozdiliv [Substantiation of the speed of fire trucks to determine the location of fire and rescue units], Naukovyi visnyk: Tsyvilnyi zakhyst ta pozhezhna bezpeka. [Scientific bulletin: civil protection and fire safety] [in Ukrainian].

4. A. Kuzyk, D. Lagno (2019). Osoblyvosti procesu likvidaciyi pozhezh u zabrudneny`x radionuklidamy lisax u zoni vidchuzhennya [Features of the fire elimination process in radionuclide-contaminated forests in the exclusion zone], Pozhezhna bezpeka [Fire Safety]. Lviv [in Ukrainian].

5. V. Bloshchytskyi, Yu. Kazanova, T. Martinenko (2010). Opredelenye optymalnogo puty sledovanyya pozharnogo rascheta k mestu pozhara s pomoshhyu evolyucyonni vichyslenyj [Determining the optimal path of fire calculation to the place of fire using evolutionary calculations], Naukovi praci Don NTU [Scientific works of Don NTU]. Donetsk [in Ukrainian].

6. A. Kuzyk, S. Emelyanenko (2013). Ocinyuvannya chasu sliduvannya pozhezhno-ryatuvalnyx pidrozdiliv [Estimation of time of following of fire and rescue divisions], Pozhezhna bezpeka [Fire Safety]. Lviv [in Ukrainian].

7. About the statement of criteria of formation of the state fire and rescue divisions (parts) of Operational and rescue service of civil defense in administrative-territorial units and the list of business entities where such divisions (parts) are formed № 874. (2013, November 27). Oficijnyj visnyk Ukrayiny, pp. 113 [in Ukrainian]. 


\title{
INFLUENCE OF THE TIME OF ARRIVAL OF FIRE PROTECTION SUBJECTS TO THE PLACE OF CALL ON THE DURATION OF FIRE EXTINGUISHING ON THE TERRITORY OF THE ALIENATION ZONE
}

\author{
A. Tsyhankov, V. Nizhnyk, Ya. Ballo, O. Sizikov, O. Zhikharev, O.Teslenko
}

Institute of Public Administration and Research in Civil Protection, Ukraine

KEYWORDS
the territory of the
Exclusion Zone,
time of arrival of
fire departments,
duration of fire
extinguishing,
number of fire
trucks.

ANNOTATION

According to the results of scientific research, the dependence of the number of involved fire trucks, human resources and the duration of firefighting in the Exclusion Zone on the time of arrival of fire-fighting units to the place of call. It was established that at the time of arrival of the fire-fighting units more than 20 minutes. almost 6 times more main and auxiliary fire trucks and up to 3 times more human resources are involved in comparison with the time of arrival to the place of fire less than 20 minutes. According to the results of research, changes and additions to additional legislative and regulatory acts to ensure fire safety in the exclusion zone and the zone of unconditional (compulsory) resettlement are scientifically substantiated. The methods of interpolation and averaging were used in the work, the analysis of normative documents, which regulate the activity of economic entities in the exclusion zone, was carried out. The research determined the distribution of fire extinguishing duration in the Exclusion Zone up to 8 hours and their corresponding relative number at the time of air defense arrival at the fire site up to 20 minutes and at the time of air defense arrival more than 20 minutes. place of fire, the dependence of the number of involved fire trucks and the average number of personnel and air defense personnel involved in extinguishing the fire from the time of arrival of air defense to the place of fire call. As a result of scientific research it was established that critical (according to the criteria: duration of firefighting in the Exclusion Zone, number of fire trucks and human resources involved in firefighting) are those fires for which the time of air defense arrival was more than 20 minutes. In such fires, the duration of their extinguishing was up to 6 times longer than the duration of extinguishing fires, for which the time of arrival of air defense was less than 20 minutes, and the involved fire trucks and human resources - 3 times. 